\title{
BMJ Open Relationship between low Ankle- Brachial Index and rapid renal function decline in patients with atrial fibrillation: a prospective multicentre cohort study
}

Francesco Violi, ${ }^{1}$ Daniele Pastori, ${ }^{1}$ Francesco Perticone, ${ }^{2}$ William R Hiatt, ${ }^{3}$ Angela Sciacqua, ${ }^{2}$ Stefania Basili, ${ }^{1}$ Marco Proietti, ${ }^{1}$ Gino R Corazza, ${ }^{4}$ Gregory Y H Lip, ${ }^{5}$ Pasquale Pignatelli, ${ }^{1}$ in collaboration with the ARAPACIS (Atrial Fibrillation Registry for Ankle-Brachial Index Prevalence AssessmentCollaborative Italian Study) STUDY group

To cite: Violi F, Pastori D, Perticone $\mathrm{F}$, et al.

Relationship between low Ankle-Brachial Index and rapid renal function decline in patients with atrial fibrillation: a prospective multicentre cohort study. BMJ Open 2015;5:e008026.

doi:10.1136/bmjopen-2015008026

- Prepublication history and additional material is available. To view please visit the journal (http://dx.doi.org/ 10.1136/bmjopen-2015008026).

Received 21 February 2015 Revised 23 April 2015 Accepted 26 April 2015

CrossMark

For numbered affiliations see end of article.

Correspondence to Professor Francesco Violi; francesco.violi@uniroma1.it

\section{ABSTRACT}

Objective: To investigate the relationship between Ankle-Brachial Index (ABI) and renal function progression in patients with atrial fibrillation (AF).

Design: Observational prospective multicentre cohort study.

Setting: Atherothrombosis Center of I Clinica Medica of 'Sapienza' University of Rome; Department of Medical and Surgical Sciences of University Magna Græcia of Catanzaro; Atrial Fibrillation Registry for Ankle-Brachial Index Prevalence AssessmentCollaborative Italian Study.

Participants: 897 AF patients on treatment with vitamin $\mathrm{K}$ antagonists.

Main outcome measures: The relationship between basal $A B I$ and renal function progression, assessed by the estimated Glomerular Filtration Rate (eGFR) calculated with the CKD-EPI formula at baseline and after 2 years of follow-up. The rapid decline in eGFR, defined as a decline in eGFR $>5 \mathrm{~mL} / \mathrm{min} / 1.73 \mathrm{~m}^{2} /$ year, and incident eGFR $<60 \mathrm{~mL} / \mathrm{min} / 1.73 \mathrm{~m}^{2}$ were primary and secondary end points, respectively.

Results: Mean age was $71.8 \pm 9.0$ years and $41.8 \%$ were women. Low ABI (ie, $\leq 0.90$ ) was present in 194 (21.6\%) patients. Baseline median eGFR was $72.7 \mathrm{~mL} /$ $\mathrm{min} / 1.73 \mathrm{~m}^{2}$, and $28.7 \%$ patients had an eGFR $<60 \mathrm{~mL} /$ $\mathrm{min} / 1.73 \mathrm{~m}^{2}$. Annual decline of eGFR was -2.0 (IQR $-7.4 /-0.4) \mathrm{mL} / \mathrm{min} / 1.73 \mathrm{~m}^{2} /$ year, and $32.4 \%$ patients had a rapid decline in eGFR. Multivariable logistic regression analysis showed that $A B I \leq 0.90$ (OR 1.516 $(95 \% \mathrm{Cl} 1.075$ to 2.139$), \mathrm{p}=0.018)$ and arterial hypertension (OR $1.83095 \% \mathrm{Cl} 1.113$ to 3.009 , $\mathrm{p}=0.017$ ) predicted a rapid eGFR decline, with an inverse association for angiotensin converting enzyme (ACE) inhibitors/angiotensin receptor blockers (OR $0.66295 \% \mathrm{Cl} 0.464$ to $0.944, \mathrm{p}=0.023)$. Among the 639 patients with AF with $\mathrm{GGF}>60 \mathrm{~mL} / \mathrm{min} / 1.73 \mathrm{~m}^{2}$, $153(23.9 \%)$ had a reduction of the eGFR $<60 \mathrm{~mL} / \mathrm{min} /$ $1.73 \mathrm{~m}^{2} . \mathrm{ABI} \leq 0.90$ was also an independent predictor

\section{Strengths and limitations of this study}

- Measurement of Ankle-Brachial Index (ABI) is a simple, inexpensive and standardised method to explore systemic atherosclerosis.

- Renal function assessment and deterioration were assessed using international definitions.

- $A B I$ measurement may help identify patients with atrial fibrillation (AF) who are at high risk of renal function deterioration, and eventually require serum creatinine monitoring.

- Our findings may turn particularly useful in the era of non-vitamin $\mathrm{K}$ antagonist oral anticoagulants, whose dosage requires to be tailored in $\mathrm{AF}$ patients with renal impairment.

- Our analysis was performed only in a Caucasian population from the same country (Italy), limiting the generalisability of the findings.

for incident eGFR $<60 \mathrm{~mL} / \mathrm{min} / 1.73 \mathrm{~m}^{2}$ (HR $1.851,95 \%$ $\mathrm{Cl} 1.205$ to $2.845, \mathrm{p}=0.005$ ).

Conclusions: In patients with $\mathrm{AF}$, an $\mathrm{ABI} \leq 0.90$ is independently associated with a rapid decline in renal function and incident eGFR $<60 \mathrm{~mL} / \mathrm{min} / 1.73 \mathrm{~m}^{2}$. ABI measurement may help identify patients with $A F$ at risk of renal function deterioration.

Trial registration number: NCT01161251.

\section{INTRODUCTION}

Atrial fibrillation (AF) is the most common arrhythmia encountered in daily clinical practice, accounting for approximately one-third of all hospitalisations for a cardiac rhythm abnormality. It is associated with a 
fivefold increase in the risk for stroke, and is estimated to be the cause of almost $15 \%$ of all strokes. ${ }^{1}$

Chronic kidney disease (CKD) is a frequent feature of patients with $\mathrm{AF}$ having an important impact on clinical outcomes, as it predisposes to both ischaemic stroke and bleeding. ${ }^{2-4}$ Diagnosis and evaluation of CKD progression is a part of comprehensive AF management, not only to prevent adverse clinical events, but also to aid decision-making on oral anticoagulation. In fact, evaluation of renal function is a key aspect when prescribing of non-vitamin $\mathrm{K}$ antagonist oral anticoagulants (NOACs), especially dabigatran. ${ }^{5}$

Ankle-Brachial Index (ABI) is a simple, inexpensive and non-invasive marker of peripheral artery disease and systemic atherosclerosis, which is associated with an increased risk of cardiovascular events. ${ }^{6}{ }^{7}$ Prior studies have reported that a low ABI (ie, $\leq 0.90$ ) is present in patients with CKD and predicts a rapid decline in renal function in the general population. ${ }^{8}$ We have recently reported that low ABI can be detected in about $20 \%$ of the AF population, ${ }^{9}$ suggesting that systemic atherosclerosis is a frequent feature in this setting. ${ }^{10}$ No prior studies have reported on the relationship between low ABI and rapid decline in renal function in patients with $\mathrm{AF}$.

We hypothesised that low ABI may predict a rapid decline in renal function and may represent a useful, rapid and simple clinical tool to risk-stratify those patients at risk of renal impairment. Thus, we analysed the relationship between low $\mathrm{ABI}$ and the occurrence of rapid renal function decline, and incident CKD as assessed by renal function $<60 \mathrm{~mL} / \mathrm{min} / 1.73 \mathrm{~m}^{2}$ during a follow-up of approximately 2 years in a large population affected by AF.

\section{METHODS}

This was an observational prospective multicentre study including patients with $\mathrm{AF}$ recruited from the Atherothrombosis Center of I Clinica Medica of 'Sapienza' University of Rome, from the Department of Medical and Surgical Sciences, University Magna Græcia of Catanzaro, Italy, and from those included in the cohort of the Atrial Fibrillation Registry for Ankle-Brachial Index Prevalence Assessment-Collaborative Italian Study (see online supplementary appendix) who had a double determination of serum creatinine.

All patients with non-valvular AF aged $>18$ years and with a follow-up of at least 1 year were included in this prospective study. Exclusion criteria were the presence of valvular diseases (prosthetic heart valves or any severe valvulopathy), chronic infectious diseases (ie, HIV infection, hepatitis $\mathrm{C}$ virus, hepatitis B virus) or autoimmune systemic disease. Subjects were also excluded from the study if they had active cancer or liver insufficiency (eg, cirrhosis). At baseline, anthropometric data as well as comorbidities and concomitant therapies were collected. The presence of cardiovascular risk factors were defined as previously described. ${ }^{11}$
At baseline, serum creatinine $(\mathrm{mg} / \mathrm{dL})$ was obtained for all patients. Estimated glomerular filtration rate (eGFR) was calculated using the CKD-EPI formula. ${ }^{12}$ Patients were classified in eGFR categories according to Kidney Disease: Improving Global Outcomes (KDIGO) guidelines: ${ }^{13}$ normal eGFR $\left(>90 \mathrm{~mL} / \mathrm{min} / 1.73 \mathrm{~m}^{2}\right.$, Stage G1), mildly decreased eGFR $\left(89-60 \mathrm{~mL} / \mathrm{min} / 1.73 \mathrm{~m}^{2}\right.$, Stage G2), moderately decreased eGFR $\left(59-30 \mathrm{~mL} / \mathrm{min} / 1.73 \mathrm{~m}^{2}\right.$, Stage G3) and severely decreased eGFR $(<30 \mathrm{~mL} / \mathrm{min} /$ $1.73 \mathrm{~m}^{2}$, Stage G4). A second serum creatinine was collected during follow-up. The primary end point of the study was to evaluate the rapid decline in eGFR defined as a loss in glomerular filtration $>5 \mathrm{~mL} / \mathrm{min} / 1.73 \mathrm{~m}^{2} /$ year. ${ }^{13}$ The secondary end point of the study was incident CKD as defined as an eGFR $<60 \mathrm{~mL} / \mathrm{min} / 1.73 \mathrm{~m}^{2}$.

\section{$A B I$ measurement}

At baseline, trained clinical staff measured the ABI in all patients using an $8 \mathrm{MHz}$ CW Vascular Doppler (Risingmed Model:RFD-B). ABI was calculated as the ratio of systolic blood pressure obtained from the ankle and brachial arteries. Ankle and brachial systolic blood pressures were measured separately for the right and left sides, and $\mathrm{ABI}$ was assessed separately for the right and left legs using the highest arm pressure as the denominator. Patients were categorised into 2 groups according to their ABI value: (1) normal, if both left and right $\mathrm{ABI}$ values were normal $(\mathrm{ABI}>0.90)$ and (2) low, if at least one of the two values of $A B I$ was $\leq 0.90$.

The local ethical boards approved the protocol study. The study was conducted according to the principles embodied in the Declaration of Helsinki, and all patients included in the present study provided written informed consent at enrolment.

\section{Statistical analyses}

Categorical variables are reported as counts (percentage). Continuous variables are expressed as mean $\pm \mathrm{SD}$ or median and interquartile range (IQR) (IQR; 25th-75th percentile), as appropriate. Two-sided t tests or the Wilcoxon rank sum test, depending on the shape of the distribution curve, was used to compare means. Pearson $\chi^{2}$ test was used to compare proportions. Bivariate analysis was performed with Pearson's linear correlation. Appropriate non-parametric tests (Mann-Whitney U test and Spearman rank correlation test) were employed for all the other variables.

We calculated the annual absolute decline in eGFR, expressed as the difference between the two eGFR values (follow-up eGFR-basal eGFR/years of follow-up).

We divided the population according to the presence or absence of a rapid decline in eGFR $(>5 \mathrm{~mL} / \mathrm{min} /$ $1.73 \mathrm{~m}^{2}$ /year), to analyse clinical characteristics of patients with renal function deterioration. We performed a multivariable logistic regression analysis to calculate the adjusted ORs of factors associated with the annual rapid decline in kidney function. 
The multivariate analysis was determined including all variables that could potentially affect renal function. In particular, we included as covariates the following variables: age, gender, $\mathrm{ABI} \leq 0.90$, type of $\mathrm{AF}$ (persistent/permanent vs paroxysmal $\mathrm{AF}$ ), presence of arterial hypertension, diabetes, heart failure, history of ischaemic stroke/transient ischaemic attack (TIA), history of myocardial infarction/cardiac revascularisation, as well as the use of angiotensin converting enzyme (ACE) inhibitors/angiotensin receptor blockers (ARBs), $\beta$ blockers, calcium channel antagonists, statins, antiplatelet therapy and body mass index.

We also analysed the clinical characteristics of patients with $\mathrm{AF}$ developing incident eGFR $<60 \mathrm{~mL}$ / $\min / 1.73 \mathrm{~m}^{2}$. Considering that the second creatinine was not collected at the same time during follow-up for all patients with AF, we used a Cox proportional hazard regression analysis to calculate the relative adjusted hazard ratios (HRs) of factors associated with incident eGFR $<60 \mathrm{~mL} / \mathrm{min} / 1.73 \mathrm{~m}^{2}$, using the same variables listed above with the addition of baseline eGFR, which has been shown to be predictive of incident eGFR $<60 \mathrm{~mL} / \mathrm{min} / 1.73 \mathrm{~m}^{2} .{ }^{14}$

All tests were two-tailed and analyses were performed using computer software packages (SPSS-V.18.0, SPSS). Only $\mathrm{p}$ values $<0.05$ were considered as statistically significant.

\section{RESULTS}

Clinical characteristics of 897 patients with AF included in the study are described in table 1 . Mean age was 71.8 \pm 9.0 years, and $41.8 \%$ were women. The median $\mathrm{CHA}_{2} \mathrm{DS}_{2}$-VASc score was 3.0 (2.0-4.0).
In the whole population, the baseline median eGFR was $72.7 \mathrm{~mL} / \mathrm{min} / 1.73 \mathrm{~m}^{2}$ (56.8-88.8), and $258(28.7 \%)$ had an eGFR $<60 \mathrm{~mL} / \mathrm{min} / 1.73 \mathrm{~m}^{2}$. Distribution of classes of eGFR in the whole cohort is reported in figure 1A. Prevalence of normal, mild, moderate and severe eGFR was $23.1 \%, 48.2 \%, 26.1 \%$ and $2.7 \%$, respectively. Using $60 \mathrm{~mL} / \mathrm{min} / 1.73 \mathrm{~m}^{2}$ as a cut-off to define the CKD, we found that patients with renal disease were older, more frequently women, with a clinical history more complicated by heart failure and myocardial infarction/coronary heart disease and with a higher $\mathrm{CHA}_{2} \mathrm{DS}_{2}$-VASc score (table 1). Moreover, a higher prevalence of permanent $\mathrm{AF}$ was found in patients with baseline eGFR $<60 \mathrm{~mL} / \mathrm{min} / 1.73 \mathrm{~m}^{2}$ (table 1 ).

In the whole cohort, 194 (21.6\%) had a value of ABI $\leq 0.90$. No significant differences of low ABI were found between paroxysmal/persistent and permanent AF (19.6 vs $24.3 \%, \mathrm{p}=0.102)$. The prevalence of reduced eGFR $\left(<60 \mathrm{~mL} / \mathrm{min} / 1.73 \mathrm{~m}^{2}\right)$ was significantly higher in patients with $\mathrm{ABI} \leq 0.90$ compared with those with $\mathrm{ABI}$ $>0.90 \quad(45.4$ vs $24.2 \%, \mathrm{p}<0.001$ ) (figure $1 \mathrm{~B}$ ). Thus, patients with ABI $\leq 0.90$ had a median eGFR of 65.0 $(46.9-82.4)$ vs $74.1 \quad(60.1-90.1) \mathrm{mL} / \mathrm{min} / 1.73 \mathrm{~m}^{2}$ in those with normal ABI $(\mathrm{p}<0.001)$.

A second measurement of serum creatinine was obtained for all patients after a median of 2.0 (1.0 3.4) years. During follow-up, median eGFR decreased significantly from a baseline of 72.7 to $63.6(48.8-82.0) \mathrm{mL} /$ $\min / 1.73 \mathrm{~m}^{2}(\mathrm{p}<0.001)$ with a parallel increase in the prevalence of impaired renal function (figure 1A). Overall, the annual median decline in eGFR was -2.0 (IQR $-7.4 /-0.4) \mathrm{mL} / \mathrm{min} / 1.73 \mathrm{~m}^{2} /$ year, with no differences between paroxysmal/persistent and permanent $\mathrm{AF}$ $(-2.1(-7.5 /-0.45)$ vs $-2.0(-7.1 /-0.30), \mathrm{p}=0.453)$.

Table 1 Baseline characteristics of entire cohort, according to the presence or absence of renal impairment (eGFR<60 $\mathrm{mL} / \mathrm{min}$ )

\begin{tabular}{|c|c|c|c|c|}
\hline & \multirow{2}{*}{$\begin{array}{l}\text { Overall } \\
(n=897)\end{array}$} & \multicolumn{2}{|c|}{$\begin{array}{l}\text { Baseline eGFR } \\
<60 \mathrm{~mL} / \mathrm{min} / 1.73 \mathrm{~m}^{2}\end{array}$} & \multirow[b]{2}{*}{ p Value } \\
\hline & & No $(n=639)$ & Yes $(n=258)$ & \\
\hline Age (years) & $71.8 \pm 9.0$ & $69.8 \pm 8.9$ & $76.7 \pm 7.3$ & $<0.001$ \\
\hline Women (\%) & 41.8 & 36.9 & 53.9 & $<0.001$ \\
\hline Permanent AF (\%) & 43.1 & 40.7 & 49.2 & 0.021 \\
\hline Body mass index $\left(\mathrm{kg} / \mathrm{m}^{2}\right)$ & $27.9 \pm 4.6$ & $28.1 \pm 4.6$ & $27.7 \pm 4.5$ & 0.300 \\
\hline Ankle-Brachial Index $\leq 0.90(\%)$ & 21.6 & 16.6 & 34.1 & $<0.001$ \\
\hline $\mathrm{CHA}_{2} \mathrm{DS}_{2}$-VASc score & $3.0(2.0-4.0)$ & $3.0(2.0-4.0)$ & $4.0(3.0-5.0)$ & $<0.001$ \\
\hline Arterial hypertension (\%) & 86.3 & 85.4 & 88.4 & 0.284 \\
\hline Diabetes mellitus (\%) & 24.1 & 22.7 & 27.5 & 0.075 \\
\hline History of Ml/CHD (\%) & 18.4 & 16.7 & 22.5 & 0.029 \\
\hline Heart failure (\%) & 19.0 & 16.4 & 25.2 & 0.003 \\
\hline History of stroke/TIA (\%) & 11.3 & 11.1 & 11.6 & 0.816 \\
\hline ACE inhibitor/ARBs (\%) & 72.8 & 71.4 & 76.4 & 0.074 \\
\hline$\beta$ blockers (\%) & 48.6 & 47.1 & 52.3 & 0.090 \\
\hline Calcium channel antagonists (\%) & 27.2 & 26.0 & 30.2 & 0.195 \\
\hline Statins (\%) & 44.4 & 43.3 & 46.9 & 0.336 \\
\hline Antiplatelets (\%) & 19.6 & 20.5 & 17.4 & 0.309 \\
\hline
\end{tabular}


A

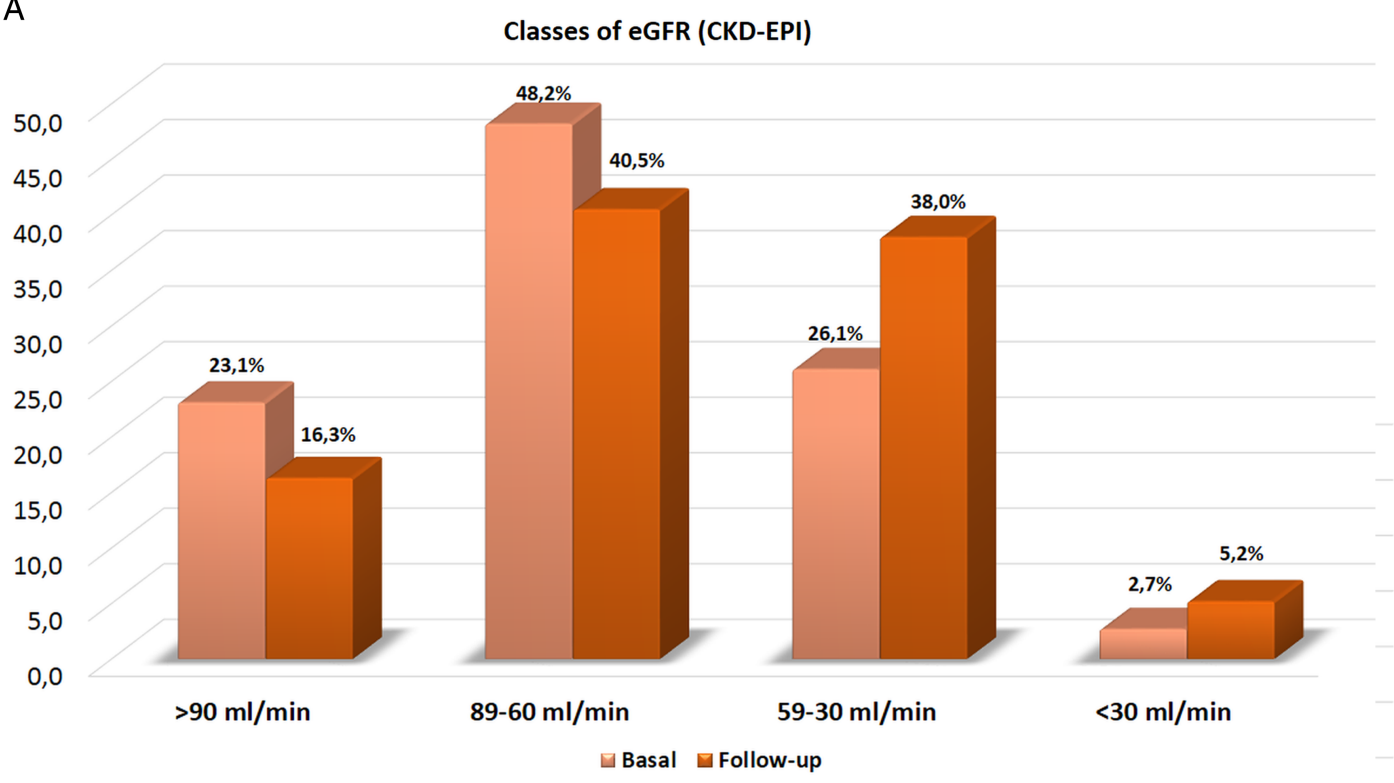

B

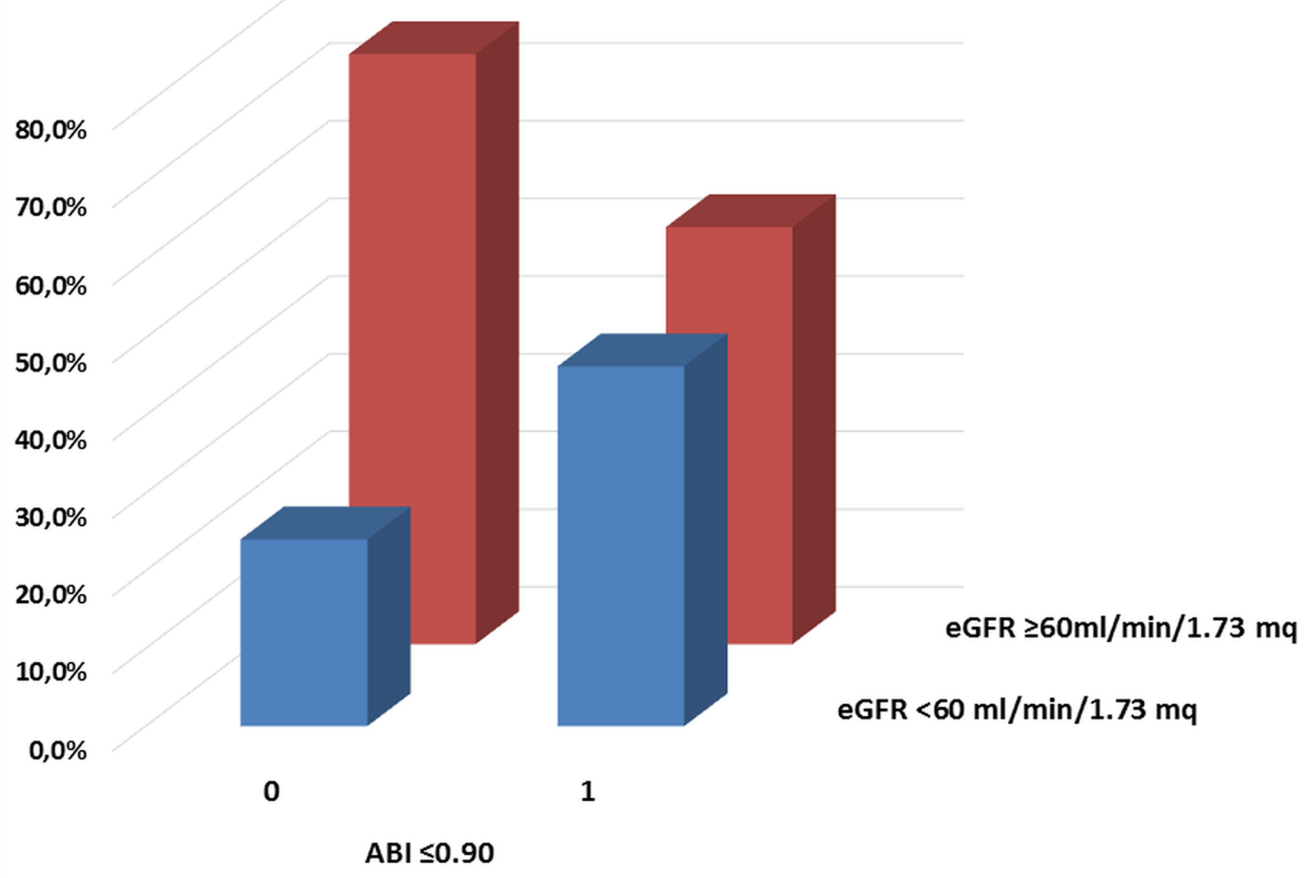

Figure 1 (A) Distribution of classes of estimated glomerular filtration rate (eGFR) in the whole cohort of patients with atrial fibrillation (AF) at baseline and during follow-up. (B) Prevalence of Ankle-Brachial Index (ABI) $>0.90$ (Row: 0$) A B I \leq 0.90$ (Row: 1) in patients with eGFR $\geq 60 \mathrm{~mL} / \mathrm{min} / 1.73 \mathrm{~m}^{2}$ (Red columns) or $<60 \mathrm{~mL} / \mathrm{min} / 1.73 \mathrm{~m}^{2}$ (Blue columns).

Patients with $\mathrm{AF}$ with $\mathrm{ABI} \leq 0.90$ showed a significantly higher deterioration of renal function compared with those with normal ABI $(-3.2(-8.3$ to -0.5$)$ vs -1.9 $(-6.8$ to -0.4$\left.) \mathrm{mL} / \mathrm{min} / 1.73 \mathrm{~m}^{2}, \mathrm{p}=0.020\right)$.

Rapid decline in renal function

Analysis of rapid deterioration in renal function showed that $291(32.4 \%)$ patients with AF had a rapid decline in
eGFR. The clinical characteristics of these patients are reported in table 2 .

The rapid decline in renal function was detected in $97(33.3 \%)$ patients with AF and normal eGFR at baseline, $148(50.9 \%)$ with mildly decreased eGFR, $44(15.1 \%)$ with moderately decreased eGFR and in 2 $(0.7 \%)$ patients with baseline eGFR severely decreased.

A multivariable logistic regression analysis (table 3) showed that factors independently predicting rapid 
Table 2 Clinical characteristics of patients with a rapid decline in renal function ( $>5 \mathrm{~mL} / \mathrm{min} / 1.73 \mathrm{~m}^{2} /$ year)

\begin{tabular}{|c|c|c|c|}
\hline & $\begin{array}{l}\text { Rapid } \\
\text { decline } \\
\text { in eGFR } \\
(n=291)\end{array}$ & $\begin{array}{l}\text { No } \\
\text { decline } \\
\text { in eGFR } \\
(n=606)\end{array}$ & p Value \\
\hline Age (years) & $72.1 \pm 8.4$ & $71.6 \pm 9.3$ & 0.486 \\
\hline Body mass index $\left(\mathrm{kg} / \mathrm{m}^{2}\right)$ & $27.5 \pm 4.5$ & $28.2 \pm 4.6$ & 0.039 \\
\hline Women (\%) & 41.9 & 41.7 & 0.960 \\
\hline Permanent AF (\%) & 42.3 & 43.6 & 0.720 \\
\hline $\begin{array}{l}\text { Ankle-Brachial Index } \\
\leq 0.90(\%)\end{array}$ & 26.5 & 19.3 & 0.015 \\
\hline Arterial hypertension (\%) & 88.7 & 85.1 & 0.152 \\
\hline Diabetes (\%) & 23.0 & 24.6 & 0.608 \\
\hline Heart failure (\%) & 19.6 & 18.6 & 0.736 \\
\hline History of stroke/TIA (\%) & 10.0 & 11.9 & 0.396 \\
\hline History of MI/CHD (\%) & 19.6 & 17.8 & 0.523 \\
\hline Antiplatelet (\%) & 18.2 & 20.3 & 0.462 \\
\hline ACE inhibitors/ARBs (\%) & 69.4 & 74.4 & 0.068 \\
\hline$\beta$ blockers (\%) & 51.5 & 47.2 & 0.222 \\
\hline $\begin{array}{l}\text { Calcium channel } \\
\text { antagonists (\%) }\end{array}$ & 27.8 & 26.9 & 0.768 \\
\hline Statins (\%) & 43.6 & 44.7 & 0.761 \\
\hline
\end{tabular}

eGFR decline were ABI $\leq 0.90$ (OR 1.516 (1.075 to 2.139), $\mathrm{p}=0.018$ ) and arterial hypertension (OR 1.830 (1.113 to 3.009), $\mathrm{p}=0.017$ ), while the use of ACE inhibitors/ARBs showed a protective effect (OR $0.662(0.464$ to 0.944$), \mathrm{p}=0.023)$.

Table 3 Multivariable-adjusted ORs of factors associated with a rapid decline in kidney function (eGFR decrease $>5 \mathrm{~mL} / \mathrm{min} / 1.73 \mathrm{~m}^{2} /$ year)

\begin{tabular}{|c|c|c|c|}
\hline & p Value & OR & $95 \% \mathrm{Cl}$ \\
\hline Age (years) & 0.988 & 0.998 & 0.741 to 1.344 \\
\hline Women (\%) & 0.819 & 0.998 & 0.981 to 1.015 \\
\hline Body mass index $\left(\mathrm{kg} / \mathrm{m}^{2}\right)$ & 0.080 & 0.955 & 0.938 to 1.004 \\
\hline $\begin{array}{l}\text { Persistent/permanent } \\
\text { AF }(\%)\end{array}$ & 0.573 & 0.919 & 0.687 to 1.231 \\
\hline $\begin{array}{l}\text { Ankle-Brachial Index } \\
\leq 0.90(\%)\end{array}$ & 0.018 & 1.516 & 1.075 to 2.139 \\
\hline Arterial hypertension (\%) & & 1.830 & 1.113 to 3.009 \\
\hline Diabetes (\%) & & .883 & .253 \\
\hline ailure (\%) & 0.969 & 0.993 & 1.443 \\
\hline History of stroke/TIA (\%) & 0.176 & 0.723 & 0.452 to 1.156 \\
\hline History of MI/CHD (\%) & 0.800 & 1.052 & 08 to 1.564 \\
\hline ACE inhibitors/ARBs (\%) & 0.023 & 0.662 & 0.464 to 0.944 \\
\hline$\beta$ blockers (\%) & 0.215 & 1.206 & 0.897 to 1.621 \\
\hline $\begin{array}{l}\text { Calcium channel } \\
\text { antagonists (\%) }\end{array}$ & 0.673 & 1.074 & 0.771 to 1.497 \\
\hline Statins (\%) & & 0.971 & 0.720 to 1.311 \\
\hline Antiplatelet (\%) & 0.464 & 0.870 & 0.600 to 1.262 \\
\hline \multicolumn{4}{|c|}{$\begin{array}{l}\text { ACE, angiotensin converting enzyme; AF, atrial fibrillation; ARBs, } \\
\text { angiotensin receptor blockers; CHD, coronary heart disease; } \\
\text { eGFR, estimated glomerular filtration rate; MI, myocardial } \\
\text { infarction; TIA, transient ischaemic attack. }\end{array}$} \\
\hline
\end{tabular}

Incident eGFR<60 mL/min/1.73 $\mathrm{m}^{2}$

At baseline, 639 (71.2\%) patients with AF had an eGFR $>60 \mathrm{~mL} / \mathrm{min} / 1.73 \mathrm{~m}^{2}$; during the follow-up, 153 $(23.9 \%)$ patients with an eGFR $>60 \mathrm{~mL} / \mathrm{min} / 1.73 \mathrm{~m}^{2}$ had an eGFR $<60 \mathrm{~mL} / \mathrm{min} / 1.73 \mathrm{~m}^{2}$. As shown in table 4 , patients with $\mathrm{AF}$ with incident $\mathrm{eGFR}<60 \mathrm{~mL} / \mathrm{min}$ / $1.73 \mathrm{~m}^{2}$ were older, more frequently women, and affected by arterial hypertension compared with those with stable renal function. Low ABI was more frequent in patients with $A F$ with incident $e G F R<60 \mathrm{~mL} / \mathrm{min} /$ $1.73 \mathrm{~m}^{2}$ (table 4 ).

A Cox regression analysis found a positive association of $\mathrm{ABI} \leq 0.90$ and age with incident $\mathrm{eGFR}<60 \mathrm{~mL} / \mathrm{min} /$ $1.73 \mathrm{~m}^{2}$, while baseline eGFR and the use of calcium channel antagonists were inversely associated (table 5).

\section{DISCUSSION}

This report shows that low ABI (ie $\leq 0.90$ ) is associated with rapid deterioration of renal function and with an increased risk of incident kidney disease in a population affected by AF. The baseline analysis of our population showed that renal impairment was common in the AF population, as only $23 \%$ of patients have a normal renal function (eGFR $>90 \mathrm{~mL} / \mathrm{min}$ ), while moderate renal impairment $(\mathrm{eGFR}<60 \mathrm{~mL} / \mathrm{min})$ was detected in approximately $30 \%$ of patients. Similar findings were seen by Roldan et al, ${ }^{3}$ who found $28 \%$ with moderate renal impairment in 978 patients affected by $\mathrm{AF}^{3}$ Furthermore, patients with AF had an annual decline in

Table 4 Characteristics of patients developing incident eGFR $<60 \mathrm{~mL} / \mathrm{min} / 1.73 \mathrm{~m}^{2}$

\begin{tabular}{|c|c|c|c|}
\hline & \multicolumn{3}{|c|}{$\begin{array}{l}\text { Incident eGFR<60 mL/min/ } \\
1.73 \mathrm{~m}^{2}\end{array}$} \\
\hline & $\begin{array}{l}\text { Yes } \\
(n=153)\end{array}$ & $\begin{array}{l}\text { No } \\
(n=486)\end{array}$ & p Value \\
\hline Age (years) & $73.2 \pm 8.2$ & $68.7 \pm 8.8$ & $<0.001$ \\
\hline Body mass index $\left(\mathrm{kg} / \mathrm{m}^{2}\right)$ & $27.5 \pm 4.5$ & $28.2 \pm 4.7$ & 0.090 \\
\hline Women (\%) & 45.1 & 34.4 & 0.016 \\
\hline Permanent AF (\%) & 39.2 & 41.2 & 0.760 \\
\hline $\begin{array}{l}\text { Ankle-Brachial Index } \\
<0.90(\%)\end{array}$ & 23.5 & 14.4 & 0.008 \\
\hline Arterial hypertension (\%) & 90.8 & 83.7 & 0.030 \\
\hline Diabetes (\%) & 18.3 & 24.1 & 0.137 \\
\hline Heart failure (\%) & 12.4 & 17.7 & 0.124 \\
\hline History of stroke/TIA (\%) & 11.1 & 11.1 & 1.000 \\
\hline History of Ml/CHD (\%) & 17.0 & 16.7 & 0.925 \\
\hline Antiplatelet (\%) & 16.3 & 21.8 & 0.087 \\
\hline ACE inhibitors/ARBs (\%) & 72.5 & 71.0 & 0.759 \\
\hline$\beta$ blockers (\%) & 49.0 & 46.5 & 0.586 \\
\hline $\begin{array}{l}\text { Calcium channel } \\
\text { antagonists (\%) }\end{array}$ & 28.1 & 25.3 & 0.492 \\
\hline Statins (\%) & 44.4 & 43.0 & 0.754 \\
\hline
\end{tabular}

$\mathrm{ACE}$, angiotensin converting enzyme; $\mathrm{AF}$, atrial fibrillation; $\mathrm{ARBs}$, angiotensin receptor blockers; $\mathrm{CHD}$, coronary heart disease; eGFR, estimated glomerular filtration rate; MI, myocardial infarction; TIA, transient ischaemic attack. 
Table 5 Adjusted HRs, based on a Cox proportional hazards analysis of factors associated with incident eGFR<60 $\mathrm{mL} / \mathrm{min} / 1.73 \mathrm{~m}^{2}$

\begin{tabular}{|c|c|c|c|c|}
\hline & p Value & HR & $95 \% \mathrm{C}$ & \\
\hline Age (years) & 0.019 & 1.030 & 1.005 & 1.056 \\
\hline $\begin{array}{l}\text { Baseline eGFR } \\
\left(\mathrm{mL} / \mathrm{min} / 1.73 \mathrm{~m}^{2}\right)\end{array}$ & $<0.001$ & 0.957 & 0.944 & 0.971 \\
\hline Body mass index $\left(\mathrm{kg} / \mathrm{m}^{2}\right)$ & 0.777 & 1.006 & 0.967 & 1.045 \\
\hline Women (\%) & 0.994 & 1.001 & 0.711 & 1.409 \\
\hline Permanent AF (\%) & 0.395 & 0.862 & 0.611 & 1.214 \\
\hline $\begin{array}{l}\text { Ankle-Brachial Index } \\
\leq 0.90(\%)\end{array}$ & 0.005 & 1.851 & 1.205 & 2.845 \\
\hline Arterial hypertension (\%) & 0.052 & 1.860 & 0.994 & 3.481 \\
\hline Diabetes (\%) & 0.151 & 0.713 & 0.449 & 1.132 \\
\hline Heart failure (\%) & 0.841 & 1.055 & 0.627 & 1.774 \\
\hline History of stroke/TIA (\%) & 0.867 & 1.046 & 0.619 & 1.767 \\
\hline History of MI/CHD (\%) & 0.172 & 0.725 & 0.457 & 1.150 \\
\hline Antiplatelet (\%) & 0.518 & 0.864 & 0.555 & 1.346 \\
\hline ACE inhibitors/ARBs (\%) & 0.442 & 0.842 & 0.543 & 1.306 \\
\hline$\beta$ blockers (\%) & 0.788 & 1.052 & 0.728 & 1.521 \\
\hline $\begin{array}{l}\text { Calcium channel } \\
\text { antagonists (\%) }\end{array}$ & 0.029 & 0.640 & 0.429 & 0.954 \\
\hline Statins (\%) & 0.434 & 1.148 & 0.812 & 1.622 \\
\hline
\end{tabular}

renal function of approximately $2-5 \mathrm{~mL} / \mathrm{min}$, which is consistent with previous data in a very old AF population. $^{15}$

To the best of our knowledge, only one previous study analysed the rate and predictors of rapid renal disease progression in AF. Roldan $e t a \hat{l}$ demonstrated a progression of $\mathrm{CKD} \geq 10 \mathrm{~mL} / \mathrm{min}$ in $21 \%$ of patients with $\mathrm{AF}$ at 2 years of follow-up, with age, female gender and arterial hypertension being significantly associated with a decline in renal function. This study, using the general definition of rapid decline in renal function $>5 \mathrm{~mL} / \mathrm{min}$ per year, ${ }^{13}$ shows a rapid function deterioration in $32.4 \%$ of patients with AF. Rapid deterioration was more evident in patients with AF with normal or mildly decreased renal function at baseline.

The novelty of this study is in the analysis of the interplay between low $\mathrm{ABI}$ and the rapid renal function deterioration in a population affected by AF. Thus far, only one study has explored this interplay in the general population, by comparing 51 participants with $\mathrm{ABI}$ $\leq 0.90$ vs 2541 with $\mathrm{ABI}>0.90$, and demonstrated that over a follow-up of 9 years, ABI $\leq 0.90$ independently predicted a rapid decline in eGFR. ${ }^{8}$ In our cohort, which included $194(21.6 \%)$ patients with $\mathrm{AF}$ with $\mathrm{ABI} \leq 0.90$, we confirm that $\mathrm{ABI} \leq 0.90$, along with hypertension, was significantly associated with a rapid decline in renal function, while the use of $\mathrm{ACE} / \mathrm{ARB}$ inhibitors was protective.

This would suggest that low ABI, in addition to being a marker of systemic atherosclerosis, represents a marker of vascular damage occurring not only in the coronary or cerebral tree, but also in the circulation of other organs such as the kidney. Unfortunately, we cannot determine if the association between low ABI and rapid decline in renal function is a reflection of atherosclerotic burden in the micro-circulation and/or macrocirculation, but this issue deserves further investigation. However, our data are in keeping with other methods exploring atherosclerosis disease, such as pulse wave velocity, which have been shown to be predictive of renal function decline in different clinical settings. ${ }^{16} 17$

Analysis of incident $\mathrm{eGFR}<60 \mathrm{~mL} / \mathrm{min} / 1.73 \mathrm{~m}^{2}$ showed that approximately $24 \%$ of AF with baseline values $>60 \mathrm{~mL} / \mathrm{min} / 1.73 \mathrm{~m}^{2}$ had renal function impairment. Further support for the role of ABI as a predictor of renal function deterioration was provided by the significant association between low ABI and incident $\mathrm{eGFR}<60 \mathrm{~mL} / \mathrm{min}$. This is in contrast to Foster et al, who found only a trend between low ABI and incident CKD, but their small sample size may perhaps account for the different findings.

This study has implications and limitations. Patients with AF have a relatively high prevalence and incidence of renal impairment which is related to $\mathrm{ABI}$, a marker of systemic atherosclerosis. This finding may turn useful particularly in the era of NOACs which are excreted, even if to a different degree by the kidney, and whose dosage requires to be tailored in case of patients with AF with moderate renal function. ${ }^{18}$

In this context, ABI measurement could be particularly useful in identifying patients who are at high risk of renal function deterioration, and will eventually require serum creatinine monitoring.

Furthermore, identification of patients at high risk of renal disease progression may be of use to identify patients who are at higher risk of cardiovascular events. Our analysis performed only in a Caucasian population is a study limitation, as it cannot be translated to other race or ethnic groups. Another limitation of the study is represented by the lack of data on proteinuria or haematuria, which can be associated with an abnormality in the urinary tract even with a preserved eGFR $(>90 \mathrm{~mL} / \mathrm{min})$ and with $\mathrm{ABI}<0.9 .{ }^{19}$ Finally, in our study, a decline in renal function has been assessed using only a second value of serum creatinine during follow-up; the analysis of renal function progression would be more appropriate by assessing more than two values of creatinine.

In conclusion, the study provides evidence that in patients with $\mathrm{AF}$, an $\mathrm{ABI} \leq 0.90$ is independently associated with a rapid decline in renal function. ABI measurement may help identify patients with AF at risk of renal function deterioration.

\section{Author affiliations}

${ }^{1}$ Department of Internal Medicine and Medical Specialties, I Clinica Medica, Atherothrombosis Center, Sapienza University of Rome, Rome, Italy

${ }^{2}$ Department of Medical and Surgical Sciences, University Magna Græcia of Catanzaro, Catanzaro, Italy

${ }^{3}$ Division of Cardiology, University of Colorado School of Medicine and CPC Clinical Research, Aurora, Colorado, USA 
${ }^{4}$ First Department of Internal Medicine, Fondazione IRCCS Policlinico San Matteo, University of Pavia, Pavia, Italy

${ }^{5}$ Centre for Cardiovascular Sciences, University of Birmingham, Birmingham, UK

Collaborators ARAPACIS (Atrial Fibrillation Registry for Ankle-Brachial Index Prevalence Assessment-Collaborative Italian Study) study group: see online supplementary appendix.

Contributors FV is responsible for the study concept and design, drafting of the manuscript and critical revision of the manuscript. DP and PP are responsible for the study concept and design, acquisition, analysis and interpretation of data and drafting of the manuscript. FP, WRH, GRC and GYHL are responsible for the interpretation of data, drafting of the manuscript and critical revision of the manuscript. AS, SB and MP are responsible for the acquisition, analysis and interpretation of data and critical revision of the manuscript.

Funding This research received no specific grant from any funding agency in the public, commercial or not-for-profit sectors.

Competing interests None declared.

Patient consent Obtained.

Ethics approval Local Ethical Board of Sapienza University of Rome.

Provenance and peer review Not commissioned; externally peer reviewed.

Data sharing statement No additional data are available.

Open Access This is an Open Access article distributed in accordance with the Creative Commons Attribution Non Commercial (CC BY-NC 4.0) license, which permits others to distribute, remix, adapt, build upon this work noncommercially, and license their derivative works on different terms, provided the original work is properly cited and the use is non-commercial. See: http:// creativecommons.org/licenses/by-nc/4.0/

\section{REFERENCES}

1. Wolf PA, Abbott RD, Kannel WB. Atrial fibrillation as an independent risk factor for stroke: the Framingham Study. Stroke 1991;22:983-8.

2. Marinigh R, Lane DA, Lip GY. Severe renal impairment and stroke prevention in atrial fibrillation: implications for thromboprophylaxis and bleeding risk. J Am Coll Cardiol 2011;57:1339-48.

3. Roldan V, Marin F, Fernandez H, et al. Renal impairment in a "real-life" cohort of anticoagulated patients with atrial fibrillation (implications for thromboembolism and bleeding). Am J Cardiol 2013;111:1159-64.

4. Apostolakis S, Guo Y, Lane DA, et al. Renal function and outcomes in anticoagulated patients with non-valvular atrial fibrillation: the AMADEUS trial. Eur Heart $J$ 2013;34:3572-9.
5. Huisman MV, Lip GY, Diener HC, et al. Dabigatran etexilate for stroke prevention in patients with atrial fibrillation: resolving uncertainties in routine practice. Thromb Haemost 2012;107:838-47.

6. Kojima I, Ninomiya T, Hata J, et al. A low ankle brachial index is associated with an increased risk of cardiovascular disease: the Hisayama study. J Atheroscler Thromb 2014;21:966-73.

7. Alzamora MT, Fores R, Pera G, et al. Ankle-brachial index and the incidence of cardiovascular events in the Mediterranean low cardiovascular risk population ARTPER cohort. BMC Cardiovasc Disord 2013;13:119.

8. Foster MC, Ghuman N, Hwang SJ, et al. Low ankle-brachial index and the development of rapid estimated GFR decline and CKD. Am J Kidney Dis 2013;61:204-10.

9. Violi F, Davi G, Hiatt W, et al. Prevalence of peripheral artery disease by abnormal ankle-brachial index in atrial fibrillation: implications for risk and therapy. J Am Coll Cardiol 2013;62:2255-6.

10. Masanauskiene E, Naudziunas A. Comparison of ankle-brachial index in patients with and without atrial fibrillation. Medicina 2011;47:641-5

11. Pastori D, Pignatelli $P$, Angelico $F$, et al. Incidence of myocardial infarction and vascular death in anticoagulated elderly patients with atrial fibrillation: Relation to atherosclerotic risk factors. Chest 2014 Published Online First 27 November 2014. doi:10.1378/chest.14-2414.

12. Levey AS, Stevens LA, Schmid CH, et al. A new equation to estimate glomerular filtration rate. Ann Intern Med 2009;150:604-12.

13. Stevens PE, Levin A, Kidney Disease: Improving Global Outcomes Chronic Kidney Disease Guideline Development Work Group Members. Evaluation and management of chronic kidney disease: synopsis of the kidney disease: improving global outcomes 2012 clinical practice guideline. Ann Intern Med 2013;158:825-30.

14. Tohidi $\mathrm{M}$, Hasheminia $\mathrm{M}$, Mohebi $\mathrm{R}$, et al. Incidence of chronic kidney disease and its risk factors, results of over 10 year follow up in an Iranian cohort. PLoS ONE 2012;7:e45304.

15. Guo $\mathrm{Y}$, Wang $\mathrm{H}$, Zhao $\mathrm{X}$, et al. Sequential changes in renal function and the risk of stroke and death in patients with atrial fibrillation. Int $J$ Cardiol 2013;168:4678-84.

16. Su HM, Lin TH, Hsu PC, et al. Brachial-ankle pulse wave velocity and systolic time intervals in risk stratification for progression of rena function decline. Am J Hypertens 2012;25:1002-10.

17. Yoon HE, Shin DI, Kim SJ, et al. Brachial-ankle pulse wave velocity predicts decline in renal function and cardiovascular events in early stages of chronic kidney disease. Int J Med Sci 2013;10:1430-6.

18. Reilly PA, Lehr T, Haertter S, et al. The effect of dabigatran plasma concentrations and patient characteristics on the frequency of ischemic stroke and major bleeding in atrial fibrillation patients: the RE-LY Trial (Randomized Evaluation of Long-Term Anticoagulation Therapy). J Am Coll Cardiol 2014;63:321-8.

19. Wattanakit K, Folsom AR, Criqui MH, et al. Albuminuria and peripheral arterial disease: results from the multi-ethnic study of atherosclerosis (MESA). Atherosclerosis 2008;201:212-16. 